\title{
Elucidation of the Oxygen Reduction Volcano in Alkaline Media using a Copper- Platinum(111) Alloy
}

Jensen, Kim Degn; Tymoczko, Jakub; Rossmeisl, Jan; Bandarenka, Aliaksandr S.; Chorkendorff, Ib; Escribano, Maria Escudero; Stephens, Ifan E. L.

\section{Published in:}

Angewandte Chemie

Link to article, DOI:

10.1002/ange.201711858

Publication date:

2018

Document Version

Peer reviewed version

Link back to DTU Orbit

Citation $(A P A)$ :

Jensen, K. D., Tymoczko, J., Rossmeisl, J., Bandarenka, A. S., Chorkendorff, I., Escribano, M. E., \& Stephens, I. E. L. (2018). Elucidation of the Oxygen Reduction Volcano in Alkaline Media using a Copper-Platinum(111) Alloy. Angewandte Chemie, 130(11), 2850-2855. https://doi.org/10.1002/ange.201711858

\section{General rights}

Copyright and moral rights for the publications made accessible in the public portal are retained by the authors and/or other copyright owners and it is a condition of accessing publications that users recognise and abide by the legal requirements associated with these rights.

- Users may download and print one copy of any publication from the public portal for the purpose of private study or research.

- You may not further distribute the material or use it for any profit-making activity or commercial gain

- You may freely distribute the URL identifying the publication in the public portal 


\title{
Elucidation of the Oxygen Reduction Volcano in Alkaline Media using a Copper-Platinum(111) Alloy
}

\author{
Kim D. Jensen, ${ }^{[a, b]}$ Jakub Tymoczko, ${ }^{[c]}$ Jan Rossmeisl, ${ }^{[b]}$ Aliaksandr S. Bandarenka, ${ }^{[d]}$ Ib

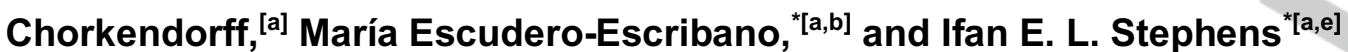

Abstract: Herein, we experimentally explore the relationship between the binding of the reaction intermediates and oxygen reduction activity in alkaline media. By introducing $\mathrm{Cu}$ into the $2^{\text {nd }}$ surface layer of a $\mathrm{Pt}(111)$ single crystal, we tune the surface reactivity. We demonstrate that in both $0.1 \mathrm{M} \mathrm{NaOH}$ and $0.1 \mathrm{M} \mathrm{KOH}$, the optimal catalyst should exhibit $\mathrm{OH}$ binding $\sim 0.1 \mathrm{eV}$ weaker than $\mathrm{Pt}(111)$, via a Sabatier volcano; this observation suggests that the reaction is mediated via the same surface bound intermediates as in acid, in contrast to previous reports. In $0.1 \mathrm{M} \mathrm{KOH}$, the alloy catalyst at the peak of the volcano exhibits a maximum activity of $101 \pm 8 \mathrm{~mA} / \mathrm{cm}^{2}$ at $0.9 \mathrm{~V} \mathrm{vs}$. a reversible hydrogen electrode $(\mathrm{RHE})$. This activity constitutes a $\sim 60$ fold increase over $\mathrm{Pt}(111)$ in $0.1 \mathrm{M} \mathrm{HClO}_{4}$.

Oxygen reduction is ubiquitous. It limits the efficiency of low temperature fuel cells and metal-air batteries for renewable energy conversion. ${ }^{[1-3]} \mathrm{A}$ huge body of research has been devoted towards elucidating the factors controlling this all-important reaction ${ }^{[4-7]}$; most studies focus on acidic media, where only Ptbased catalysts are able to provide the stability and activity required for technological applications. ${ }^{[8]}$ A theoretical model was developed to show that a Sabatier volcano relationship exists between the binding of ${ }^{*} \mathrm{OH}$ (where * denotes an adsorbed species) and the catalytic activity ${ }^{[4,9]}$ : the most optimal metal catalyst should bind ${ }^{*} \mathrm{OH}, 0.1 \mathrm{eV}$ weaker than $\mathrm{Pt}(111)$. This volcano exists because the reaction proceeds via a series of proton-coupled electron transfers to the surface-bound reaction intermediates, ${ }^{*} \mathrm{OOH},{ }^{*} \mathrm{O}$ and ${ }^{*} \mathrm{OH}$; the binding energies of all these intermediates scale linearly together. ${ }^{5}$ In an earlier work, we experimentally verified that the oxygen reduction volcano holds in $0.1 \mathrm{M} \mathrm{HClO}_{4}$, by modifying a $\mathrm{Pt}(111)$ single crystal with subsurface $\mathrm{Cu}$ to form a Cu/Pt(111) near-surface alloy ${ }^{[10]}$ (see Fig. 1a). By lieu of the ligand effect, ${ }^{[11,12]}$ we systematically tuned $\mathrm{OH}-$

[*] Dr. I. E. L. Stephens

Department of Materials, Imperial College London, Royal School of Mines, Prince Consort Rd, London SW7 2AZ, United Kingdom E-mail: i.stephens@imperial.ac.uk

Asst. Prof. M. Escudero-Escribano

Department of Chemistry - Nano-Science Center, University of

Copenhagen (KU), Universitetsparken 5, 2100, Kbh. Ø, Denmark E-mail: maria.escudero@chem.ku.dk

[a] Dr. K. D. Jensen, Prof. I. Chorkendorff, Asst. Prof. M. EscuderoEscribano,Sr. Lecturer I. E. L. Stephens, Department of Physics, Technical University of Denmark (DTU), Fysikvej, 2800, Kgs. Lyngby, Denmark

[b] Dr. K. D. Jensen, Prof. J. Rossmeisl, Asst. Prof. M. Escudero-Escribano, Department of Chemistry - Nano-Science Center, University of Copenhagen (KU), Universitetsparken 5, 2100, Kbh. Ø, Denmark

[c] Dr. J. Tymoczko, Analytical Chemistry - Center for Electrochemical Sciences (CES), Ruhr-Universität Bochum, Universitätsstr. 150, D-44780 Bochum, Germany

[d] Asst. Prof. A. S. Bandarenka, Energy Conversion and Storage (ECS), Physik-Department, Technische Universität München, James-Franck-Str. 1, 85748 Garching, Germany

[e] Dr. I. E. L. Stephens, Department of Materials, Imperial College London, Royal School of Mines, Prince Consort Rd, London SW7 2AZ, United Kingdom

Supporting information (SI) for is available via ((Placeholder for SI link))

adsorption, which we monitored through the position of the voltammetric peak for this process. The experimental relationship between the voltammetric shift for ${ }^{*} \mathrm{OH}$ adsorption and oxygen reduction activity extends to Pt-based single-crystalline surfaces reported by others, ${ }^{[13]}$ including stepped single crystals ${ }^{[14-16]}$ and $\mathrm{Pt}_{3} \mathrm{Ni}(111)^{[17]}$. Knowledge of the volcano has provided catalyst developers with the key design principle for the reaction. It has led to the huge decrease in the amount of $\mathrm{Pt}$ required in commercial fuel cells today. ${ }^{[18-20]}$

The scope of oxygen reduction reaction (ORR) research is increasingly extending beyond acidic media, ${ }^{[21-25]}$ augmented by advances in hydroxide conducting polymeric membranes. ${ }^{[26]} \mathrm{At}$ high $\mathrm{pH}$, a much wider range of materials are stable, including Ag${ }^{[27]}$ and Fe-based ${ }^{[28]}$ electrodes. Shao-Horn and coworkers have elucidated the factors controlling oxygen reduction on oxide surfaces in basic electrolytes. ${ }^{[29,30]}$ Nonetheless, there is little consensus regarding the factors that control oxygen reduction on metal surfaces in alkaline media. For example, one recent study ${ }^{[31]}$ suggested that oxygen reduction proceeds via an ${ }^{*} \mathrm{OOH}$ surface intermediate, similar to acid. However, other reports suggest that the trends in activity in alkaline media are different from those in acid. Bulk polycrystalline and nanoparticulate $\mathrm{Pt}$ are a factor of $\sim 2$ less active in $0.1 \mathrm{M} \mathrm{KOH}$ than in $0.1 \mathrm{M} \mathrm{HClO}_{4}{ }^{\left[{ }^{[32]}\right.}$ In $0.1 \mathrm{M} \mathrm{HClO}_{4}$, stepped surfaces exhibit improved activity over $\mathrm{Pt}(111)^{[33]}$; in $0.1 \mathrm{M} \mathrm{NaOH}$ they are less active than $\mathrm{Pt}(111){ }^{[23]}$ Conversely, $\mathrm{Pt}_{3} \mathrm{Ni}(111)$, exhibits a $\sim 130$-fold enhancement in 0.1 $\mathrm{M} \mathrm{KOH}$ over $\mathrm{Pt}(111)$ in $0.1 \mathrm{M} \mathrm{HClO}_{4} .^{[17,24]} \mathrm{Au}(100)$, which is relatively inactive in $0.1 \mathrm{M} \mathrm{HClO}_{4},{ }^{[34]}$ exhibits an activity equal to $\mathrm{Pt}(111)$ in $0.1 \mathrm{M} \mathrm{KOH}^{[24]}$. Several authors have proposed that in base, oxygen reduction proceeds via a proton-decoupled electron transfer step involving the superoxide anion species, $\mathrm{O}_{2}{ }^{-}$rather than ${ }^{*} \mathrm{OOH},{ }^{[21,23,32]}$ meaning a Sabatier volcano would not be applicable.

Aside from $\mathrm{pH}$, non-covalent interactions induced by the electrolyte cation ${ }^{[36-38]}$ also govern ${ }^{*} \mathrm{O}$ and ${ }^{*} \mathrm{OH}$ formation on single crystal surfaces. Such phenomena seem to play a strong role on catalytic activity, both for oxygen reduction and other electrochemical reactions. ${ }^{[25,39,40]}$ However, on $\mathrm{Pt}(111)$, when changing the cation, there is no clear trend between the positions of the peaks for $\mathrm{OH}$-adsorption and the oxygen reduction activity ${ }^{[36]}$; this observation suggests that the cation changes the oxygen reduction activity by means that go beyond simply adjusting the binding of the reaction intermediates.

The seemingly discordant observations described above provide the motivation for our current work. In particular, we aim to determine whether the catalytic activity follows a Sabatier volcano in alkaline media. Moreover, we compare the role of changing the electrolyte ${ }^{[41]}$ with changing the binding of surface intermediates.

In brief, we prepared the $\mathrm{Cu} / \mathrm{Pt}(111)$ near-surface alloys using our previously developed methodology, as follows ${ }^{[42]}$ : a $\mathrm{Pt}(111)$ single crystal was annealed and positioned in the headspace above the electrolyte in a custom electrochemical cell (see Fig. $\mathrm{S} 1$ and S2). Up to a monolayer (ML) of $\mathrm{Cu}$ was electrodeposited on the crystal and inductively annealed in the headspace in $\mathrm{Ar} / \mathrm{H}_{2}(5 \%)$, driving the $\mathrm{Cu}$ subsurface. Using angle resolved $\mathrm{X}$ ray photoelectron spectroscopy (AR-XPS), we verified that the desired near-surface alloy structure ${ }^{[10]}$ had formed and that it was stable in alkaline solution - within the range of experimental error 
- as shown in Fig. 1 (see SI for details). The AR-XPS derived $\mathrm{Cu}$ :Pt ratios of Fig. $1 \mathrm{~b}$ are in line with earlier reports. ${ }^{[10,43]}$ They indicate that when more than $0.5 \mathrm{ML} \mathrm{Cu}$ is initially deposited, some Cu may be lost into the Pt(111) bulk.

Following the formation of the near-surface alloy, the sample was mounted into the arbor of a rotating ring-disk electrode assembly and transferred to a three-electrode cell containing 0.1 $\mathrm{M} \mathrm{HClO}_{4}$ to perform base voltammetry. Subsequently the electrodes were transferred to another cell, containing $0.1 \mathrm{M} \mathrm{KOH}$ $(\mathrm{pH}=12.8 \pm 0.3)$.
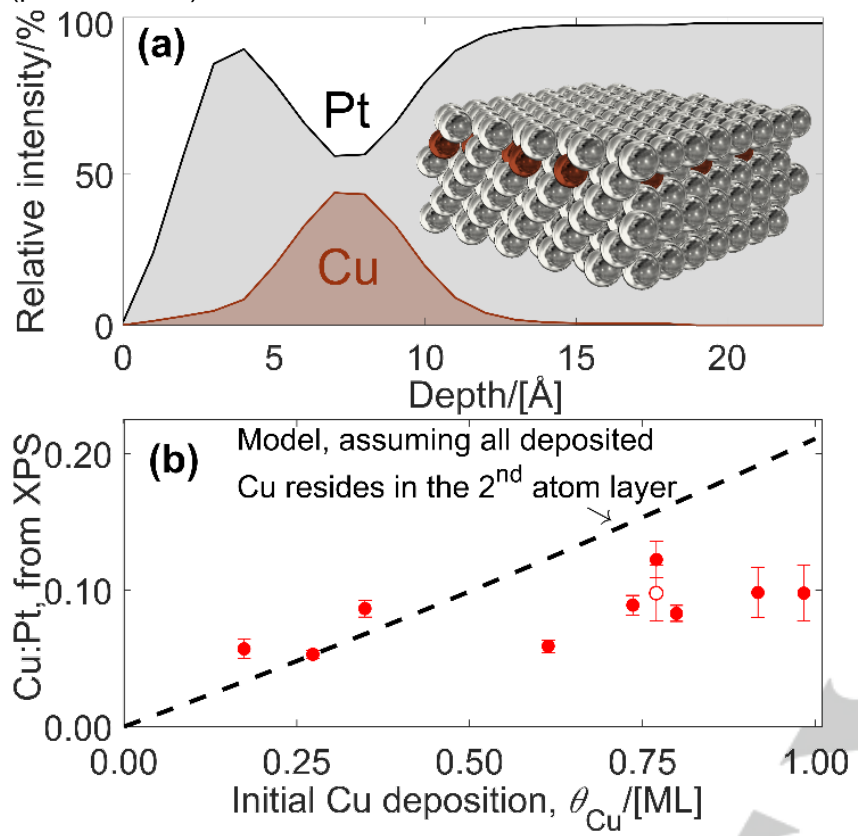

Figure 1. AR-XPS data. (a) Profile of a Cu/Pt(111) near-surface alloy with $\sim 0.77 \mathrm{ML} \mathrm{Cu}$ in the $2^{\text {nd }}$ atom layer (Pt4f, Cu2 $\mathrm{p}_{3 / 2}, \mathrm{O} 1 \mathrm{~s}$ and $\mathrm{C} 1 \mathrm{~s}$ peaks were utilized, $\mathrm{O} 1 \mathrm{~s}$ and $\mathrm{C} 1 \mathrm{~s}$ contributions are not shown). Inset: schematic illustration of the surface structure. (b) Averaged $\mathrm{Cu}$ : Pt ratios derived at angles from 20 to $35^{\circ}$ with standard deviation error compared to a mode[ [10] wherein all $\mathrm{Cu}$ is assumed to resides in the $2^{\text {nd }}$ atom layer. Open point represents a sample following exposure to electrochemical tests in $\mathrm{KOH}$

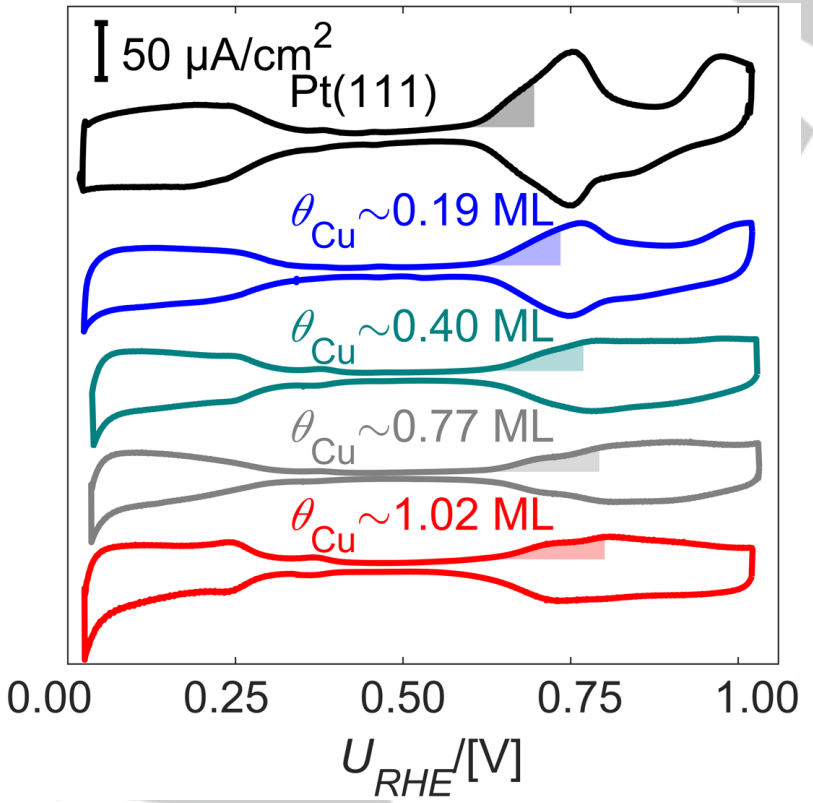

Figure 2. Base $\mathrm{CVs}$ of $\mathrm{Pt}(111)$ and $\mathrm{Cu} / \mathrm{Pt}(111)$ near-surface alloys $\left(\mathrm{N}_{2}\right.$ saturated $0.1 \mathrm{M} \mathrm{KOH}$ at $400 \mathrm{rpm}, 23^{\circ} \mathrm{C}$ and $50 \mathrm{mV} / \mathrm{s}$ ) with varying initial $\mathrm{Cu}$ coverages, $\theta$ cu. Filled areas represent the charge required to form $1 / 6 \mathrm{ML}{ }^{*} \mathrm{OH}$.
We used $\mathrm{CVs}$ in $\mathrm{N}_{2}$-saturated $\mathrm{KOH}$ to probe the interaction of the surface with the electrolyte, as shown in Fig. 2. We focus on the peak(s) positive of $0.6 \mathrm{~V}$, which is associated with ${ }^{*} \mathrm{OH}$ or ${ }^{*} \mathrm{O}$ adsorption. ${ }^{[44]}$ For the purpose of brevity, here we will assume it is due to ${ }^{*} \mathrm{OH}$; this assumption will not significantly affect our analysis. Clearly, increased amounts of $\mathrm{Cu}$ in the subsurface destabilize ${ }^{*} \mathrm{OH}$ or ${ }^{*} \mathrm{O}$; this phenomenon is manifested as the positive shift in the peak associated with ${ }^{*} \mathrm{OH}$ or ${ }^{*} \mathrm{O}$ adsorption, at potentials positive of $0.6 \mathrm{~V}$. In Fig. $3 a$ and 4 we quantify this destabilization by comparing the shift in potential required to form $1 / 6 \mathrm{ML} \mathrm{OH}$ (equivalent to $40 \mu \mathrm{C} / \mathrm{cm}^{2}$ ), relative to $\mathrm{Pt}(111)$ given by $\Delta U_{\theta_{\mathrm{OH}} * \mathrm{OH} \mathrm{ML}}=\Delta U_{\theta_{\mathrm{OH}} * \mathrm{OH} \mathrm{ML}}^{\mathrm{Cu} /(111)}-\Delta U_{\theta_{\mathrm{OH}} * \mathrm{OH} \mathrm{ML}}^{\mathrm{Pt}(11)}$ (see Fig. 2 and S7). On Fig. 3a, we have co-plotted (i) the average experimental shift, $\Delta U_{1 / 6 \mathrm{ML} * \mathrm{OH}}$ in $0.1 \mathrm{M} \mathrm{KOH}$ and $0.1 \mathrm{M} \mathrm{HClO}_{4}$ as a function of the amount of $\mathrm{Cu}$ initially deposited (ii) the theoretical shift, $\Delta \Delta E_{\mathrm{OH}}$ as a function of $\mathrm{Cu}$ in the $2^{\text {nd }}$ surface layer, from our earlier publication. ${ }^{[10]}$ All three curves are in qualitative agreement; however, as we noted in our previous work, ${ }^{[10]}$ the theoretical destabilization is more pronounced than the experimental value, particularly at $\theta c_{u}>0.5 \mathrm{ML}$; this divergence is consistent with the XPS analysis in Fig. 1b, which indicated that high coverages of $\mathrm{Cu}$ cannot be sustained in the $2^{\text {nd }}$ surface layer of $\mathrm{Pt}(111)$.

Cu coverage in the $2^{\text {nd }}$ layer/[ML]

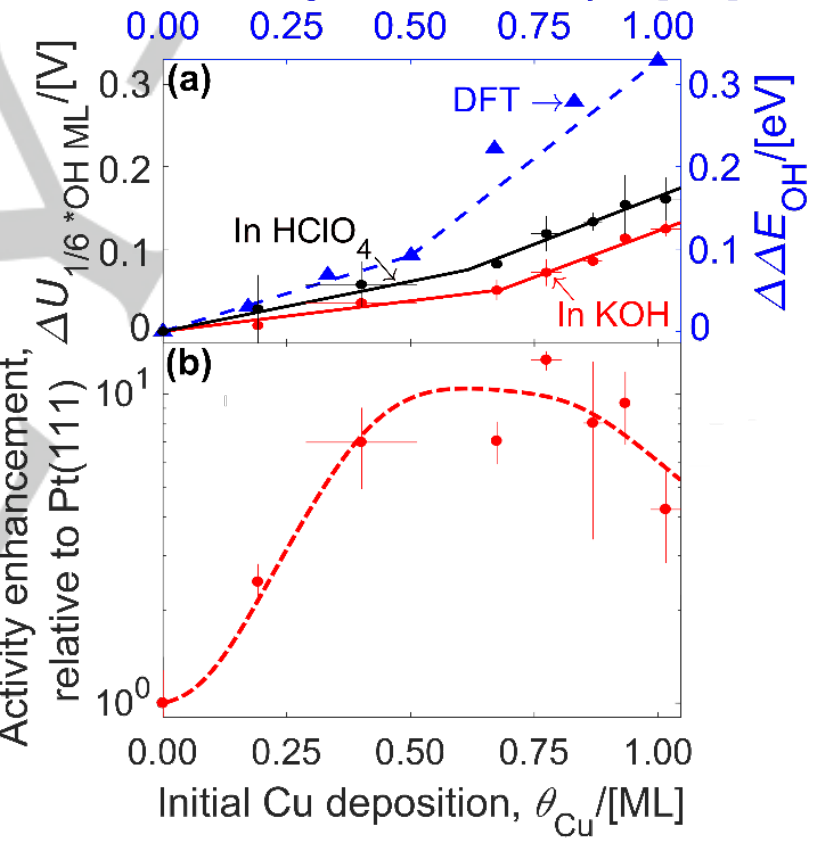

Figure 3. $\mathrm{Cu} / \mathrm{Pt}(111)$ data as function of initial $\mathrm{Cu}$ coverage. (a) Potential shift in $\mathrm{OH}$-adsorption (for $1 / 6{ }^{*} \mathrm{OH} \mathrm{ML}$ ) in $0.1 \mathrm{M} \mathrm{HClO}_{4}$ and $\mathrm{KOH}$ co-plotted with DFT model ${ }^{[10]}$ of the shift in $\mathrm{OH}$ binding energy compared to $\mathrm{Pt}(111)$ as function of $\mathrm{Cu}$ in the $2^{\text {nd }}$ atom layer (blue axis and plot). (b) Activity enhancement relative to $\mathrm{Pt}(111)$ in $0.1 \mathrm{M} \mathrm{KOH}$. Lines have been inserted as guides for the eyes. Each experimental data point is based on two to four independent measurements; the error bar shows the standard deviation.

The shift in $0.1 \mathrm{M} \mathrm{HClO}_{4}$ is up to $0.02 \mathrm{~V}$ more pronounced than in $0.1 \mathrm{M} \mathrm{KOH}$, possibly due to the different local environments of ${ }^{*} \mathrm{OH}$ and ${ }^{*} \mathrm{O}$ induced by each electrolyte.

Following the base $\mathrm{CV}$ measurements in $\mathrm{N}_{2}$, we saturated the electrolyte with $\mathrm{O}_{2}$ and rotated the electrode at $1600 \mathrm{rpm}$, in order to probe the kinetics of oxygen reduction. We compare the activities at $0.9 \mathrm{~V}$ vs. RHE. As shown in Fig. $3 \mathrm{~b}$ and $\mathrm{S} 14$, the oxygen reduction activity is improved in the presence of subsurface $\mathrm{Cu}$. We found up to a $\sim 10$-fold improvement over $\mathrm{Pt}(111)$ in $\mathrm{KOH}$, with a maximum at the initial coverage of $\sim 0.77 \mathrm{ML} \mathrm{Cu}$. 
Fig. 4 shows the activity enhancement as a function of the voltammetric shift in the $\mathrm{OH}$-adsorption peak in various alkaline electrolytes. Despite a small shift in the peak position, the trend in alkaline is remarkably similar to $0.1 \mathrm{M} \mathrm{HClO}_{4}$ see Fig. S12c and $\mathrm{S} 13$.

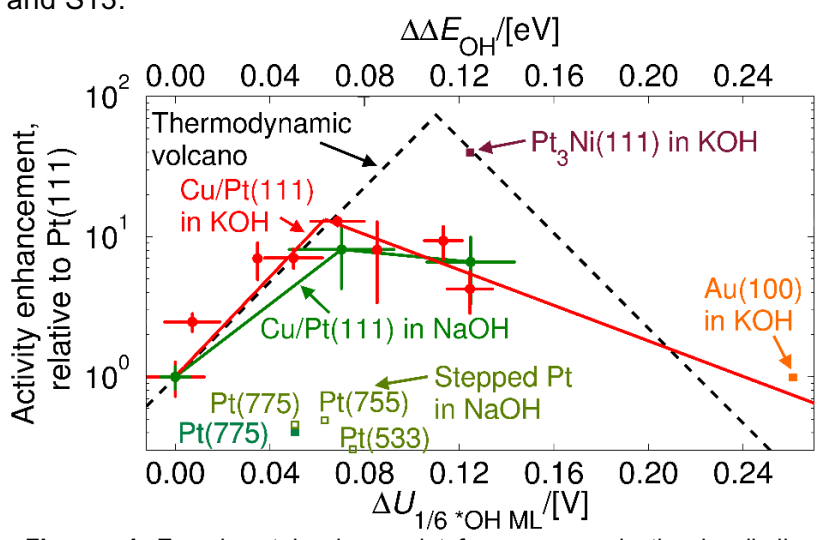

Figure 4. Experimental volcano plot for oxygen reduction in alkaline media. The activity enhancement (at $0.9 \mathrm{~V}$ vs. RHE, see Fig. $3 \mathrm{~b}$ ) plotted as a function of the voltammetric shift for $\mathrm{OH}$-adsorption (see Fig. 3a) both metrics relative to $\mathrm{Pt}(111)$ in $0.1 \mathrm{M} \mathrm{KOH}$ and $\mathrm{NaOH}$. The data for $\mathrm{Cu} / \mathrm{Pt}(111)$ near-surface alloys are from the current study. These are compared to data from the literature: $\mathrm{Pt}_{3} \mathrm{Ni}(111)$ and $\mathrm{Au}(100)$ in $0.1 \mathrm{M} \mathrm{KOH}^{[24]}$; Stepped $\mathrm{Pt}$ in $\mathrm{NaOH}^{[23,44]}$ evaluated from the activity at $0.8 \mathrm{~V}$ vs. RHE (open squares); at $0.9 \mathrm{~V}$ vs. RHE, it was only possible to find activity data for $\mathrm{Pt}(111)$ and $\mathrm{Pt}(775)$ (closed square); $(\mathrm{Pt}(533)$ was compiled from data in both 0.1 and $0.05 \mathrm{M} \mathrm{NaOH}$ ). The thermodynamic volcano is based on an earlier DFTbased model..$^{[4,9]}$

On Fig. 4, we have also co-plotted data from Markovic, Stamenkovic and coworkers on other low index facets in $0.1 \mathrm{M}$ $\mathrm{KOH}$, namely $\mathrm{Au}(100)$ and $\mathrm{Pt}_{3} \mathrm{Ni}(111)^{[24]}$; remarkably, these data also fit quite well with the predictions of the Sabatier volcano. Thus, we suggest that in $\mathrm{KOH}$, the binding of the reaction intermediates is also the key descriptor for oxygen reduction. In order to determine whether our findings may apply to other alkaline electrolytes, we also tested a selected number of $\mathrm{Cu} / \mathrm{Pt}(111) \mathrm{NSA}$ samples in $0.1 \mathrm{M} \mathrm{NaOH}$ $(\mathrm{pH}=12.5 \pm 0.3$, see Fig. S8). Notably, $\mathrm{Pt}(111)$ in $0.1 \mathrm{M} \mathrm{NaOH}$ shows a $\sim 2$-fold activity increase over $0.1 \mathrm{M} \mathrm{HClO}_{4}$, whereas in $0.1 \mathrm{M} \mathrm{KOH}$ there is a $\sim$-fold increase in activity over $0.1 \mathrm{M}$ $\mathrm{NaOH}$. Hence, changing the cation from $\mathrm{K}$ to $\mathrm{Na}$ plays just as strong a role as changing $\mathrm{pH}$ by 12 units. Moreover, Fig. S8a shows that in terms of modulating the interaction with ${ }^{*} \mathrm{OH}$, the effect of subsurface alloying $\mathrm{Cu}$ into $\mathrm{Pt}(111)$ is largely the same in $\mathrm{NaOH}$ as in $\mathrm{KOH}$.

It is also worth comparing our data with experiments ${ }^{[23,44]}$ on stepped Pt in alkaline; as shown in Fig. 4 (and S12b), the base CVs are similar to those of the Cu/Pt(111) near-surface alloy, i.e. they also exhibit mildly weakened ${ }^{*} \mathrm{OH}$ or ${ }^{*} \mathrm{O}$ binding compared to $\mathrm{Pt}(111)$; even so, the activity of the stepped surfaces is actually lower than Pt(111). Thus, as shown in Fig. 4 , the activity of the stepped surfaces in base deviates significantly from the Sabatier volcano, whereas the activity of the alloy surfaces, which are all (111)-oriented, follow the Sabatier volcano trend. We should also reiterate that in $0.1 \mathrm{M}$ $\mathrm{HClO}_{4}$, the same stepped Pt surfaces are well described by the Sabatier volcano ${ }^{[13]}$ (shown in Fig. S12c). Consequently, we suggest that in base, the presence of steps introduces additional kinetic barriers to oxygen reduction, that are absent on low index facets. Notably, these barriers are unrelated to the binding of the reaction intermediates; we speculate they are related to proton transfer through the electrochemical double layer. ${ }^{[45]}$

With respect to Fig. 4 (and S12a), the case of $A u(100)$ is of particular interest: in $0.1 \mathrm{M} \mathrm{KOH}$ the shift between $\mathrm{Pt}(111)$ and $\mathrm{Au}(100)$ is equal to $\sim 0.3 \mathrm{~V}$, which approximate the DFT calculated shift of $0.35 \mathrm{eV}^{\left[{ }^{[9]}\right.}$ Conversely, in $0.1 \mathrm{M} \mathrm{HClO}_{4}$, the shift between the peak for $\mathrm{OH}$-adsorption on $\mathrm{Pt}(111)$ and $\mathrm{Au}(100)$ is equal to $\sim 0.6 \mathrm{~V}$ (see SI for details), explaining the exceedingly low activity of $\mathrm{Au}(100)$ in acid. ${ }^{[34]}$ Consequently, our analysis of the experimental data suggest that it may not be necessary to invoke the superoxide mechanism to describe the activity of $\mathrm{Au}(100)$ in base. ${ }^{[21,23,32]}$ We offer a simpler explanation: in alkaline media, ORR proceeds via the same adsorbed intermediates as for $\mathrm{Pt}$ in acid, in particular ${ }^{*} \mathrm{OOH}$ and ${ }^{*} \mathrm{OH}$; the high activity of $\mathrm{Au}(100)$ in base is due to the favorable binding to these surface adsorbates, as described by the Sabatier volcano (see Fig. 4). Our observations suggest that the more pertinent question - beyond the scope of the current work - is why is ${ }^{*} \mathrm{OH}$ on $\mathrm{Au}(100)$ excessively destabilized in acid?

In conclusion, we have demonstrated that in alkaline media, it is possible to tune the activity of $\mathrm{Pt}(111)$ surfaces with subsurface $\mathrm{Cu}$, consistent with a ligand effect. $\mathrm{Pt}(111)$ is $\sim 4$ fold more active in $0.1 \mathrm{M} \mathrm{KOH}$ than $0.1 \mathrm{M} \mathrm{HClO}_{4}$; the activity in $0.1 \mathrm{M} \mathrm{NaOH}$ is intermediate between the two. Capitalizing on the synergy between the electrode and electrolyte, we tailored the surface to achieve ORR activities of up to $101 \pm 8 \mathrm{~mA} / \mathrm{cm}^{2}$ at $0.9 \mathrm{~V}$ vs. RHE.

Through voltammetric analysis of our data and those of others, we confirm experimentally, for the first time, that a Sabatier volcano exists for oxygen reduction on metal surfaces in alkaline media. We thus provide the key design principle for the reaction in base. The two significant outliers in our current understanding of oxygen reduction are $\mathrm{Au}(100)$ in $\operatorname{acid}^{[34]}$ and stepped $\mathrm{Pt}$ surfaces in base. ${ }^{[23]}$ We conclude that further studies are needed to understand the role of cations ${ }^{[41,46]}$ and $\mathrm{pH}^{[47]}$ at the electrochemical interface.

\section{Acknowledgements}

The authors gratefully acknowledge the Innovation fund Denmark for the KDFuelCell project and Villum Foundation VSUSTAIN grant 9455 to the Villum Center for the Science of Sustainable Fuels and Chemicals. M.E.-E. acknowledges funding from the Danish Council for Independent Research under the Sapere Aude - Research Talent Program.

Keywords: oxygen reduction - Sabatier principle - surface chemistry $\cdot$ electrocatalysis $\cdot$ platinum $\cdot$ single crystal

[1] M. K. Debe, Nature 2012, 486, 43-51.

[2] V. R. Stamenkovic, D. Strmcnik, P. P. Lopes, N. M. Markovic, Nat. Mater. 2017, 16, 57--69.

[3] X. Gao, Y. Chen, L. Johnson, P. G. Bruce, Nat. Mater. 2016, 15, DOI 10.1038/NMAT4629.

[4] J. K. Nørskov, J. Rossmeisl, A. Logadottir, L. Lindqvist, D.- Lyngby, H. Jo, J. R. Kitchin, T. Bligaard, H. Jónsson, ournal Phys. Chem. B 2004, 108, 17886-17892.

[5] S. Mukerjee, S. Srinivasan, P. M. Soriaga, J. McBreen, J. Electrochem. Soc. 1995, 142, 1409.

[6] T. Toda, H. Igarashi, H. Uchida, M. Watanabe, J. Electrochem. Soc. 1999, 146, 3750-3756.

[7] M. Escudero-Escribano, P. Malacrida, M. H. Hansen, U. G. Vej-Hansen, A. Velazquez-Palenzuela, V. Tripkovic, J. Schiotz, J. Rossmeisl, I. E. L. Stephens, I. Chorkendorff, Science (80-. ). 2016, 352, 73-76. 
[8] A. Rabis, P. Rodriguez, T. J. Schmidt, ACS Catal. 2012, 2, 864-890.

[9] V. Viswanathan, H. A. Hansen, J. Rossmeisl, J. K. Nørskov, J. Phys. Chem. Lett. 2012, 3, 2948-2951.

[10] I. E. L. Stephens, A. S. Bondarenko, F. J. Perez-alonso, F. Calle-vallejo, L. Bech, T. P. Johansson, A. K. Jepsen, R. Frydendal, B. P. Knudsen, J. Rossmeisl, et al., J. Am. Chem. Soc. 2011, 133, 5485-5491.

[11] E. H. Hoster Dr, B. O. Alves, M. T. M. Koper, ChemPhysChem 2009, 11, 1518.

[12] J. R. Kitchin, J. K. Nørskov, M. A. Barteau, J. G. Chen, Phys. Rev. Lett. 2004, 93, 156801.

[13] A. S. Bandarenka, H. A. Hansen, J. Rossmeisl, I. E. L. Stephens, Phys. Chem. Chem. Phys. 2014, 16, 1362513629.

[14] A. Kuzume, E. Herrero, J. M. Feliu, J. Electroanal. Chem. 2007, 599, 333-343.

[15] A. Hitotsuyanagi, M. Nakamura, N. Hoshi, Electrochim. Acta 2012, 82, 512-516.

[16] K. Kodama, R. Jinnouchi, N. Takahashi, H. Murata, Y. Morimoto, J. Am. Chem. Soc. 2016, 138, 4194-4200.

[17] V. R. Stamenkovic, B. Fowler, B. S. Mun, G. Wang, P. N. Ross, C. a Lucas, N. M. Marković, Science 2007, 315, 493-497.

[18] B. H. Han, C. E. Carlton, A. Kongkanand, R. S. Kukreja, B. R. Theobald, L. Gan, R. O'Malley, P. Strasser, F. T. Wagner, Y. Shao-Horn, Energy Environ. Sci. 2015, 8, 258-266.

[19] O. Gröger, H. A. Gasteiger, J. Suchsland, J. Electrochem. Soc. 2015, 162, A2605-A2622.

[20] A. Kongkanand, M. F. Mathias, J. Phys. Chem. Lett. 2016, 7, 1127-1137.

[21] J. Suntivich, K. J. May, H. A. Gasteiger, J. B. Goodenough, Y. Shao-Horn, Science (80-. ). 2011, 334, 1383-1385.

[22] P. Quaino, N. B. Luque, R. Nazmutdinov, E. Santos, W. Schmickler, Angew. Chemie Int. Ed. 2012, 51, 1299713000.

[23] R. Rizo, E. Herrero, J. M. Feliu, Phys. Chem. Chem. Phys. 2013, 15, 15416-25.

[24] J. Staszak-Jirkovský, R. Subbaraman, D. Strmcnik, K. L. Harrison, C. E. Diesendruck, R. Assary, O. Frank, L. Kobr, G. K. H. Wiberg, B. Genorio, et al., ACS Catal. 2015, 5, 6600-6607.

[25] F. Calle-Vallejo, M. T. M. Koper, A. S. Bandarenka, Chem. Soc. Rev. 2013, 42, 5210-30.

[26] J. R. Varcoe, P. Atanassov, D. R. Dekel, A. M. Herring, M. A. Hickner, P. A. Kohl, A. R. Kucernak, W. E. Mustain, K. Nijmeijer, K. Scott, et al., Energy Environ. Sci. 2014, 7, 3135-3191.

[27] A. Holewinski, J. Idrobo, S. Linic, Nat. Chem. 2014, 6, 828-834.

[28] Y. Hu, J. O. Jensen, W. Zhang, L. N. Cleemann, W. Xing, N. J. Bjerrum, Q. Li, Angew. Chem. Int. Ed. Engl. 2014, 53, 3675-9.
[29] K. A. Stoerzinger, W. T. Hong, G. Azimi, L. Giordano, Y. L. Lee, E. J. Crumlin, M. D. Biegalski, H. Bluhm, K. K. Varanasi, Y. Shao-Horn, J. Phys. Chem. C 2015, 119, 18504-18512.

[30] J. Suntivich, H. A. Gasteiger, N. Yabuuchi, H. Nakanishi, J. B. Goodenough, Y. Shao-horn, Nat. Chem. 2011, 3, 546-550.

[31] F. Lu, Y. Zhang, S. Liu, D. Lu, D. Su, M. Liu, Y. Zhang, P. Liu, J. X. Wang, R. R. Adzic, et al., J. Am. Chem. Soc. 2017, 139, 7310-7317.

[32] M. Nesselberger, S. Ashton, J. C. Meier, I. Katsounaros, K. J. J. Mayrhofer, M. Arenz, J. Am. Chem. Soc. 2011, 133, 17428-17433.

[33] F. Calle-Vallejo, M. D. Pohl, D. Reinisch, D. Loffreda, P. Sautet, A. S. Bandarenka, Chem. Sci. 2017, 8, 22832289.

[34] B. B. Blizanac, C. A. Lucas, M. E. Gallagher, M. Arenz, P. N. Ross, N. M. Marković, J. Phys. Chem. B 2004, 108, 625-634.

[35] M. T. M. Koper, Chem. Sci. 2013, 4, 2710-2723.

[36] D. Strmcnik, K. Kodama, D. van der Vliet, J. Greeley, V. R. Stamenkovic, N. M. Marković, Nat. Chem. 2009, 1, 466-472.

[37] M. Escudero-Escribano, M. E. Z. Michoff, E. P. M. Leiva, N. M. Marković, C. Gutiérrez, A. Cuesta, Chemphyschem 2011, 12, 2230-4.

[38] D.-Y. Kuo, J. K. Kawasaki, J. N. Nelson, J. Kloppenburg, G. Hautier, K. M. Shen, D. G. Schlom, J. Suntivich, J. Am. Chem. Soc. 2017, 139, 3473-3479.

[39] M. R. Singh, Y. Kwon, Y. Lum, J. W. Ager, A. T. Bell, J. Am. Chem. Soc. 2016, 138, 13006-13012.

[40] A. Ganassin, V. Colic, J. Tymoczko, A. S. Bandarenka, W. Schuhmann, Phys. Chem. Chem. Phys. 2015, 17, 8349-8355.

[41] X. Chen, I. McCrum, K. Schwarz, M. Janik, M. T. M. Koper, Angew. Chemie Int. Ed. 2017, DOI 10.1002/anie.201709455.

[42] A. S. Bondarenko, I. E. L. Stephens, I. Chorkendorff, Electrochem. commun. 2012, 23, 33-36.

[43] J. Knudsen, A. U. Nilekar, R. T. Vang, J. Schnadt, E. L. Kunkes, J. A. Dumesic, M. Mavrikakis, F. Besenbacher, J. Am. Chem. Soc. 2007, 129, 6485-6490.

[44] M. J. T. C. Van Der Niet, N. Garcia-Araez, J. Hernández, J. M. Feliu, M. T. M. Koper, Catal. Today 2013, 202, 105-113.

[45] I. Ledezma-Yanez, W. D. Z. Wallace, P. SebastiánPascual, V. Climent, J. M. Feliu, M. T. M. Koper, Nat. Energy 2017, 2, 17031.

[46] X. Wang, Y. Orikasa, Y. Takesue, H. Inoue, M. Nakamura, T. Minato, N. Hoshi, Y. Uchimoto, J. Am. Chem. Soc. 2013, 135, 5938-5941.

[47] K. A. Stoerzinger, R. R. Rao, X. R. Wang, W. T. Hong, C. M. Rouleau, Y. Shao-Horn, Chem 2017, 2, 668-675. 


\section{COMMUNICATION}
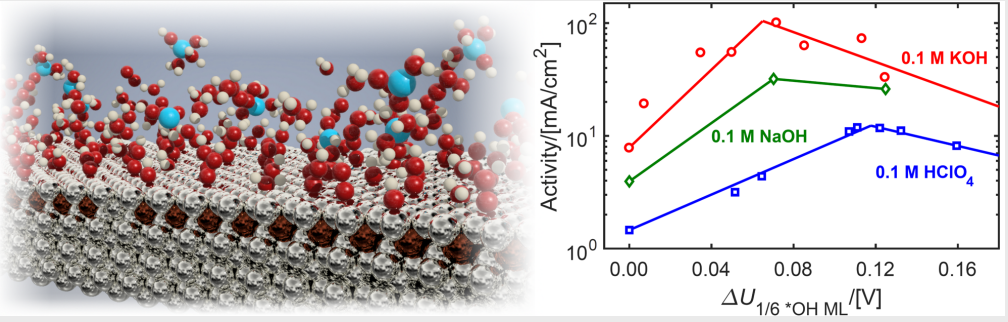

Alloying $\mathrm{Cu}$ into the subsurface of $\mathrm{Pt}(111)$ tunes the oxygen reduction activity in basic electrolytes. Just the same as in acid, the key descriptor controlling the reaction is the binding to the intermediates.
Kim D. Jensen, Jakub Tymoczko, Jan Rossmeisl, Aliaksandr S. Bandarenka, Ib Chorkendorff, María Escudero-

Escribano, ${ }^{*}$ and Ifan E. L. Stephens ${ }^{*}$

Page No. - Page No.

Elucidation of the Oxygen Reduction Volcano in Alkaline Media using a Copper-Platinum(111) Alloy 